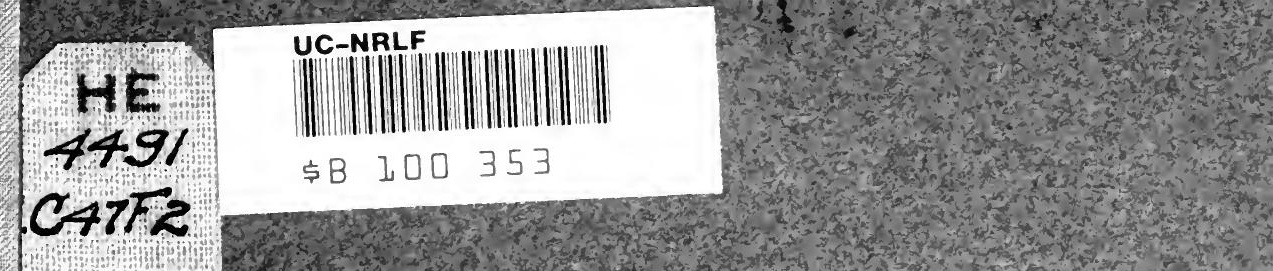



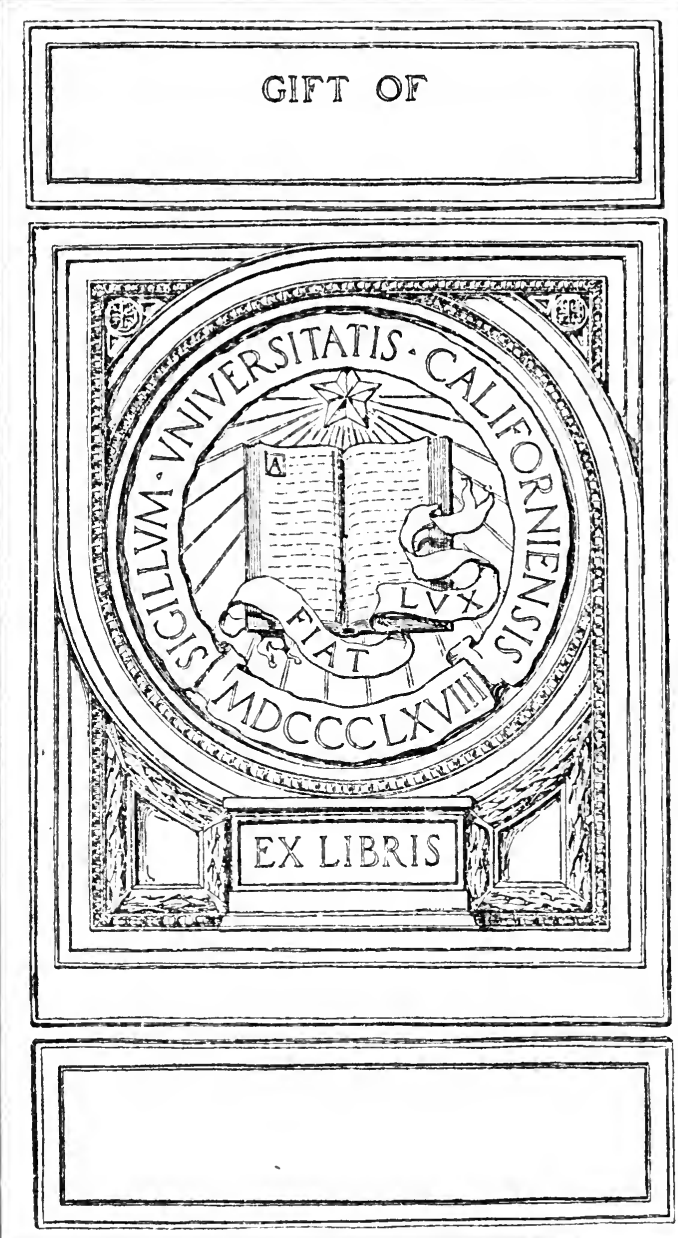


\section{THE STREET RAILWAY QUESTION IN CHICAGO}

BY

\section{JOHN A. FAIRLIE}

UNIVERSITY OF MICHIGAN

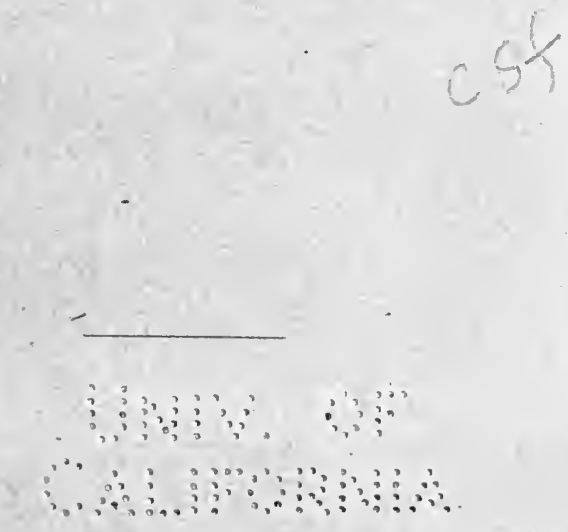

REPRINTED FROM

The Quarterly Journal of Economics

VOL. XXI., MAY, $1907^{\circ}$ 


\section{HE 4491 \\ $\mathrm{C}_{47} \mathrm{~F}_{2}$ \\ $\ldots T H E \ldots$}

\section{QUARTERLY JOURNAL OF ECONOMICS}

\section{Published for Harvard University}

Is established for the advancement of knowledge by the full and free discussion of economic questions. The editor's assume no responsibility for the views of contributors, beyond a guarantee that they have a good claim to the attention of well-informed readers.

Communications for the editors should be addressed to the Quarterly Journal of Economics, Cambridge, Mass.; business communications and subscriptions (\$3.00 a year), to Geo. H. Ellis Co., 272 Congress Street, Boston, Mass.

\section{CONTENTS FOR FEBRUARY, 1907}

I. THE TAXATION OF CORPORATIONS IN MASSACHUSETTS . Charles J. Bullock

II. CAPITAL AND INTEREST ONCE MORE: II. A Relapse to the

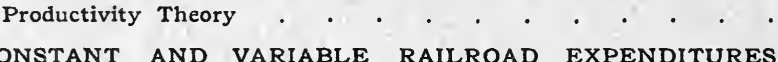

III. CONSTANT AND VARIABLE RAILROAD EXPENDITURES
AND THE DISTANCE TARIFF .

IV. THE SOCIALIST ECONOMICS OF KARL MARX AND HIS FOLLOWERS. II. . . . . . . . . . . . Thorstein Veblen

V. LABOR ORGANIZATION AND LABOR POLITICS, 1827-37 . . John R. Commons NOTES AND MEMORANDA:

An Assize of Bread at Mobile, Alabama.

William O. Scroggs The German Imperial Inheritance Tax

Frank A. Fetter RECENT PUBLICATIONS UPON ECONOMICS.

\section{CONTENTS FOR.MAY, 1907}

I. CONCERNING THE NATÚRE OH CAPITAL: A REPLY • . John Bates Clark

II. THE STREET RAIJWA Q . . John A. Fairlie

III. THE READJUSTMENT OF SAN DOMINGO'S FINANCES • Jacob H. Hollander

IV. THE CONCEPT OF AN ECONOMIC QUANTITY . . . . . . T. N. Carver

V. BANK RESERVES IN THE UNITED STATES, CANADA, AND ENGLAND • • • • . . • • • • • . • • . F. S. Mead

VI. ENGLISH FINANCES UNDER THE LONG PARLIAMENT . William O. Scroggs NOTES AND MEMORANDA:

Laws Regulating the Migration of Russians through Germany

E. A. Goldenweiser The Wisconsin Tax Decisions of 1906 .

. T. S. Adams RECENT PUBLICATIONS 


\section{THE STREET RAILWAY QUESTION IN CHICAGO.}

ON April 2 the people of Chicago, by a decisive vote, agreed to certain ordinances which mark a turning-point in the street railway history of that city, and provide at least a temporary settlement to a controversy that dates back for more than forty years, and has been actively contested for the past decade. The story of thi longcontinued struggle is important, not only because Chicago is the second largest city in the country, but also as part of the larger contest that is being carried on, more or less openly, in most of our American cities. And the arrangements in these Chicago ordinances set a new standard in the relations between street railway companies and public authorities that will have an effect throughout the United States.

In relating this story, it will be necessary, in order to understand some of the most recent events, to begin with the earliest street railways in Chicago. But the early history and the first stages of the more active contest will be discussed briefly. The greater part of this paper will deal with the events of the past ten years, and more particularly with the final steps and the terms of the settlement that has been made. The contest has important political aspects; and to some these have seemed more important than the transportation problems. But in this account, while some attention will be given to the political bearings, the emphasis will be laid on the legal, economic, and administrative features 
The earliest attempts to furnish cheap local transportation in Chicago, as in other cities, was by means of omnibuses operating on regular lines of travel. The first omnibus line of which there is any record was established in 1850 , when the city had a population of 28,000 , and ran from the business centre to Lincoln Park. Other lines were established in the years following; and by 1855 there were altogether ten omnibus lines in operation, covering an aggregate distance of $18 \frac{1}{4}$ miles. At first each line was begun by different managers; but in 1855 the operation of several lines was consolidated under the management of Franklin Parmalee \& Co. For a few years more the omnibus traffic continued to develop; but with the opening of street railways it rapidly declined. By 1861 only two omnibus lines were in operation; and by 1865 all had been discontinued. ${ }^{1}$ More recently a few new omnibus lines have been established, but these form a negligible factor in the means of passenger transportation in the city of Chicago.

A local student has discovered a newspaper notice of a local grant authorizing the construction of a street railway in Chicago as early as 1854. And there is official record of a council ordinance of 1856 , granting a street railway franchise. But no action was taken on either of these; and the latter was forfeited by the failure to secure the required consent of the owners of adjacent property. The first effective ordinance for the construction and operation of street railways in Chicago was passed by the city council, August 16, 1858. As the terms of this ordinance were involved in the recent litigation and settlement, it is of especial importance to understand its contents

1 George B. Goodwin, Chicago Street Railways. A manuscript essay in the possession of Professor J. H. Gray, of Northwestern University. 
and significance. It authorized a group of individualsincluding Franklin Parmalee, the head of the partnership then operating the principal omnibus lines-to construct railway tracks on certain streets on the south and west, of the Chicago River, and to operate cars thereon "with animal power only" for a period of twenty-five years, and until the city should "elect to purchase" the plant and equipment. A maximum fare of five cents was specified; and the grantees were to pay one-third of the cost of grading and paving streets. The council reserved the right to regulate the rate of speed and the time of running cars. Under this ordinance, tracks were laid, and the first line opened in April, 1859.

Meanwhile a question had been raised as to the legal authority of the city council to grant such a franchise. To settle these doubts and to incorporate the grantees, a special act of the Illinois legislature was passed on February 16, 1859 , incorporating the grantees under the city ordinance as the Chicago City Railway Company, for a period of twenty-five years, and authorizing the construction and operation of street railways upon terms and conditions provided by the common council. Authority was also given to extend the lines to any part of Cook County, by the exercise of the power of eminent domain, or with the assent of the supervisor of any township for laying tracks in the highways. The same powers were granted to another group of individuals, as the North Chicago City Railway Company, for the north division of the city and county.

On May 23, 1859, the council passed ordinances granting rights in important streets to both of these companies. The ordinance to the Chicago City Railway Company was, in substance, a reaffirmation of the ordinance of 1858 , on the basis of the act of the legislature. The ordinance to the North Chicago City Railway Company for the first 
time gave that company rights in specified streets, and differed from the ordinance of 1858 in limiting the grant to the term of twenty-five years "and no longer."

On February 21, 1861, the Illinois legislature passed an act which incorporated the Chicago West Division Railway Company, with the same powers as the two previously established companies, but required the consent of the North Chicago Company before the construction of any tracks in the north division, and authorized the new company to acquire any of the rights of the City Railway Company. In the summer of 1863 the City Railway Company transferred to the West Division Company control over its lines in the west division of the city.

These measures, which form the first stage in the development of the street railway system of Chicago, have been held by the United States Supreme Court to have established clearly the policy of municipal control, and in particular to recognize the right of the city to fix the term during which the streets might be occupied by street railway companies.

That it was the intention of the legislature to give effect to the right of municipal control in the act under consideration [that of 1859] is shown in its confirmation of terms already fixed by contract between the city and the companies. As to the future, companies were to have no right to the use and occupancy of the streets until they should obtain from the city council authority to that end, under contracts to be agreed upon as to terms and conditions. A more comprehensive plan of securing the city in the control of the use of the streets for railway purposes could hardly be devised.

It thus clearly appears, at least up to the passage of the act of 1865 , that legislation upon the subject recognized and enforced the right and authority of the city to fix the term during which the streets might be occupied by street railway companies. The legislature had confirmed the ordinance of the city fixing the term at twenty-five years and until the city should see fit to pur- 
chase the property of the railway company. It had required the companies to obtain the authority of the city before using the streets, such use to be upon terms and conditions, and with such rights and privileges as the city had or might thereafter prescribe by contract with the companies. ${ }^{1}$

From time to time the council passed other ordinances authorizing new lines of railway tracks and making minor changes in previous grants. In most cases these ordinances contained a definite time limit. Under them additional lines were built; and by 1865 there were forty miles of street railways in the city.

In that year another act dealing with horse railways in Chicago was passed by the legislature, which vitally affected the situation, laid the basis for the extreme claims of the companies in the recent litigation, and more than anything else has been responsible for the long agitation in reference to street railways in that city. This act, passed in February 6, 1865, was amendatory of the previous acts of 1859 and 1861. It clearly extended the corporate lines of the companies to a period of ninety-nine years from the dates of the original acts. It also added to the section authorizing the construction and operation of railways on the terms provided by the council the following confused and ambiguous clause,-

and any and all acts or deeds of transfer of rights, privileges, or franchises, between the corporations in said several acts named, or any two of them, and all contracts, stipulations, licenses, and undertakings, made, entered into, or given; and as made or amended by and between the said common council and any one or more of the said corporations, respecting the location, use or exclusion of railways in or upon the streets or any of them, of said city, shall be deemed and held and continued in force during the life hereof as valid and effectual, to all intents and purposes, as if made a part, and the same are hereby made a part of said several acts. 
Before this measure was enacted, it was strongly opposed in the city of Chicago, and a petition, signed by 9,000 citizens, was presented against its passage. When the bill reached Governor Oglesby, he refused to sign it, and returned it to the legislature with a vigorous message in opposition. But the plans of the companies had been well laid, and the bill was promptly passed over the governor's veto, by a vote of 18 to 5 in the Senate and 55 to 23 in the House.

Under this act the companies have claimed that their franchises were extended to a period of ninety-nine years from 1859 and 1861. And they asserted this claim, not only in reference to grants made before the passage of the act of 1865 , but also in reference to subsequent grants. On the other hand, the city always denied the validity of these claims. But for forty years the matter was not brought into the courts where the precise effect of the act could receive a judicial interpretation.

However the act of 1865 might be interpreted, the protest against its obvious intent to assert the authority of the legislature in local matters soon led to a return to the earlier policy of local control and short-term franchises. The new Constitution of Illinois, adopted in 1870, contained a provision prohibiting the legislature from granting street railway rights in any city, town, or incorporated village without requiring the consent of the local authorities. This policy was continued in the general act of 1872 for the incorporation of cities, which required all street railway franchises granted thereafter to be limited to twenty years. This provision became applicable to Chicago when that city adopted the act in 1875. The same end had been secured by a provision in the Horse and Dumny Act of 1874, also limiting future street railway grants to twenty years. And various franchises were granted from time to time under these acts for the further extension of the Chicago street railways. 
Under the provisions of the first ordinances and legislative acts, the grants made in 1858 should have expired, or at least have been terminable in 1883. At that time the questions were extensively discussed, and, if claims had been pressed either by the city or the companies, a determination might have been reached. The Citizens' Association appointed a committee to investigate the matter. Two of the three members reported that the original contract made by the city in 1858 was ultra vires and void, and that the companies held their rights under the act of 1865. The third member (George F. Harding) argued that the act of 1859 had confirmed the grants made the year before, and that the act of 1865 simply extended the lives of the corporations, holding that any extension of the franchises provided by the act was void as an impairment of the contract previously made.

In view of these circumstances a temporary compromise was effected. The city council in July, 1883, passed an ordinance extending the term of all existing franchises for twenty years, and providing that neither this grant nor its acceptance by the companies should alter the existing rights, duties, and obligations of either party. By this means the controversy over the ninety-nine year act was postponed until the expiration of this grant in 1903. In this same year (1883) a new company, the Chicago Passenger Railway Company, had been incorporated and received franchises for twenty years to build and operate additional lines on the west side.

II.

Until 1880 the street railways of Chicago had been operated with horses, and the business developed had not been sufficient to attract the attention of large financial 
promoters. But soon after this date there was introduced, first, cable traction, and, later, electric power. These changes of motive power were made without any new grant from the city council or the legislature, altho the earlier franchises had been given distinctly for railways to be operated only by animal power. And in connection with the new methods of traction and the reconstruction of the lines there appeared on the scene new managers, new financial interests, and striking methods of speculative financiering.

$\int$ Cable traction was first established in 1881 on the most important lines of the City Railway Company on the south side. In a few years a large proportion of the lines of this company had been converted to the new system. After $\checkmark$ 1890, electric power was introduced on many of the lines. In connection with these improvements large issues of stocks and bonds were made from time to time. In 1880 the total capital liabilities had been $\$ 1,500,000$ in stock. By 1897 there were outstanding $\$ 16,600,000$ in stock and bonds, against which the plant and equipment on the books of the company represented an investment of about $\$ 11,600,000$. $^{1}$

But these transactions appear small in comparison with those for the north and west side lines. Here the original companies were dilatory in taking steps to introduce the new methods, and no active steps were taken until 1886.

* Beginning in that year, Mr. Charles T. Yerkes, a broker who had recently come to Chicago from Philadelphia, with the assistance of Messrs. Elkins and Widener and other Philadelphia capitalists, secured control of a majority of the stock of the North Chicago and West Division Companies. Two new companies were organized which leased the lines of the original companies and also those of the Chicago Passenger Railway. New securities were

${ }^{1}$ Report of Investigation by the Civic Federation in Municipal Affairs, vol. v.: 439. 
issued, and physical improvements, reconstruction, and extensions were carried out. As a result, at the end of ten years (in 1897) the total capital liabilities of the north and west side lines had been increased from less than $\$ 8,000,000^{1}$ to $\$ 58,700,000$. The cost value of the plant and equipment at the latter date, according to the books of the companies, was $\$ 29,750,000$, and this included a large profit to inside construction companies formed by the leading capitalists controlling the companies owning and operating the lines.

Combining the financial operations of all these companies, the total capital liabilities had been increased from $\$ 9,500,000$ to more than $\$ 75,000,000$ in 1897 , while the original cost of construction had been but little over $\$ 40,000,000$. $^{2}$

In carrying out his extensive schemes, Mr. Yerkes had deemed it advisable to exercise an active but, so far as possible, a secret influence in political affairs. He became the dominant factor in nominating conventions, and had control over both city and State governments, so far at least as his business interests were concerned. And the period of his dominance, in the early nineties, marks the deepest degradation of both the city council of Chicago and the State legislature of Illinois. His success up to this point encouraged him to enter on more far-reaching plans. But these very plans served at last to arouse the public opinion of the community and to inaugurate an effective movement for the betterment of political conditions both in city and State.

In 1895 bills were introduced and passed in the legislature to confer new franchise rights more valuable than could be granted by the council. These were, however, blocked by the veto of Governor Altgeld. Two years later,

1 Even this was much in excess of the cost of construction up to that time.

2 Op. cit. 
with a more pliant governor in the executive chair, the attempt was renewed. A series of bills known as the Humphrey Bills were introduced, comprising franchises for fifty years with no safeguards for the public interests and no compensation for what were now clearly seen to be privileges of immense financial value. But public sentiment in Chicago was now thoroughly aroused, and was vigorously expressed in a series of public meetings. The protests were carried to the legislature, and were, in part, effective by preventing the passage of the original bills. There was enacted, however, with the approval of the $\checkmark$ governor, the Allen Law, authorizing city councils to grant street railway franchises for fifty years' periods and in other ways strengthening the position of the companies. ${ }^{1}$

A short time before this the city council of Chicago would have readily granted franchises under the Allen Law. But in 1896 the Municipal Voters' League had been organized, and had already improved the general character of the council by securing the election of better men. Other members who might have been subject to improper influences knew that their actions were more closely watched than formerly. The attitude of Mayor Carter Harrison, Jr., in opposition to any grant under the Allen Law, also aided in preventing any action. Not only was no grant made, but it was clearly indicated that no further grants would be made until that law was repealed. In the legislative elections of 1898 the vote on the Allen Law was made an issue in many districts, and a large number of members who had voted for the law were defeated for renomination or re-election. And the law was promptly repealed by the legislature of 1899 .

At the April municipal election of 1899, following the repeal of the Allen Law, Mayor Harrison was re-elected

${ }^{1}$ J. H. Gray, Quarterly Journal of Economics, October, 1897. 
for a second term; and, mainly through the work of the Voters' League, the council had now a clear majority of members that could be trusted to vote against any franchise that did not protect the interests of the community. Under these circumstances, Mr. Yerkes decided to retire. The Chicago Union Traction Company was organized by the Elkins-Widener-Whitney syndicate, which took over Mr. Yerkes's holdings and entered into new leases with the underlying companies to operate both the north and west side lines. This eliminated Mr. Yerkes from the situation, but the process of financial manipulation continued.

At the same time the companies definitely adopted the policy of refusing to make further improvements in the service on the ground that capital could not be secured without additional franchises. The cable lines were clearly antiquated, the track and rolling stock were allowed to deteriorate, with the obvious purpose of forcing the grant of a new franchise on terms to be dictated by the companies. Later events showed clearly that there was no justification for the plea that improvements could not be made without new grants. For in two of the three divisions of the city the companies, under their original franchises, could not be dispossessed until they were paid full value for their plant and equipment. Moreover, the companies maintained at the same time their claims under the ninety-nine year act, and on the basis of these claims and the constantly increasing traffic were actively engaged in floating new securities and piling up the obligations on their rapidly deteriorating equipment. An elaborate investigation, made under the direction of the Civic Federation in 1901, showed that the aggregate capital liabilities of the companies had then a face value of $\$ 117,000,000$ and a market value of $\$ 120,000,000$,-an increase of more than $\$ 40,000,000$ since 1897 . At the same time the 
original cost value of assets was $\$ 56,000,000$,or $\$ 15,000,000$ more than in 1897. Making conservative allowances for depreciation, the market value of the assets was but $\$ 45,840,000$; and, if the inter-company obligations representing no physical property were deducted, the net value $\checkmark$ of the physical property was only $\$ 34,750,000{ }^{1}$

\section{III.}

In the early stages of the contest with Mr. Yerkes and the companies, the energies of public-spirited citizens and the local authorities had been directed to the negative task of defeating the plans of the former for extending and making more secure their control over the local transportation service and the political situation. The development of a constructive policy was a task of even greater difficulty, $V$ and one that has taken a good many years to bring to its present outcome. The first step in this direction was the appointment by the council, late in 1897, of a special committee to collect and collate information on the subject

$\checkmark$ of street railways. This committee in March of the following year submitted a detailed report on the franchises, operations, and finances of the various companies, and on the wages of employees and the conditions of employment. $\checkmark$ It made no specific recommendations; ${ }^{2}$ but, nevertheless, this report, known as the Harlan report, from Alderman John Maynard Harlan, the first member of the committee, forms the starting-point for the policy later developed.

Another step was taken in December, 1899, when the city council passed resolutions creating a Street Railway Commission, which was in fact a committee of the council

${ }^{1}$ M. R. Maltbie, in Municipal Affairs, vol. v. p. 450.

${ }^{2}$ Report of the Special Committee of the City Council of Chicago on Street Railway Franchises and Operations, March 28, 1898. 
to examine the feasibility of municipal ownership of street railways and also the terms and conditions on which new franchises might be granted. This Commission, of which Alderman Milton J. Foreman was chairman, submitted its report in December, 1900, known commonly in Chicago as the Sikes report, from Mr. George C. Sikes, the Secretary of the Commission. This report favored, among other things, the unification of management of all street railways in the city, the prohibition of overcapitalization, publicity in the conduct of the business, and the reservation of broad powers of control by the city in any future franchises. It also urged that the city should secure from the legislature an enabling act authorizing mitnicipal ownership, as a reserve power to place the city in a better position to make terms with private corporations. ${ }^{1}$ A bill to carry out these recommendations was submitted with the report, providing for a popular referendum on street railway franchises, authorizing municipal ownership, and-after a referendum vote-municipal operation. The bill was introduced in the legislature in 1901, but was not reported by the committees of either House.

Carrying out one of the recommendations of the Commission, the city council in 1901 created a special Committee on Local Transportation. After the election of April, 1901, ${ }^{2}$ this committee was made a permanent standing committee; and this committee, with changes in its membership from time to time, has had charge of the subsequent development of the municipal policy. As a result of its first year's work, the committee formulated and submitted to the council an outline of the provisions that should be included in any franchise renewal ordinance. This outline specified that

\footnotetext{
ber, 1900.

1 Report of the Street Railway Commission to the City Council of Chicago, Decem-
}

2 At which Mayor Harrison was elected for a third term. 
such a franchise should be granted for twenty years, with a proviso that the city might purchase at any time after the expiration of the first ten years of the grant. It further provided that the companies should waive absolutely all claims under the ninety-nine year act. And it reserved to the city council large powers of control, and required the construction of underground trolley lines in the business centre of the city. Nothing definite, however, was accomplished. The companies were not ready to accept these terms. And the city authorities were also willing to wait until the expiration of the twenty-year extension ordinance in 1903.

- While the official authorities of the city were thus preparing for a renewal of the franchises, popular sentiment was advancing more rapidly in favor of the policy of municipal ownership. And the strength of this sentiment was clearly shown at a popular referendum in April, 1902. This vote was taken under an Illinois statute of 1901, known as the Public Opinion Law, under which, on petition of 25 per cent. of the registered voters, questions of public policy may be submitted to popular vote. These votes have no legal binding effect; but are merely an indication of popular opinion. Before the spring election of 1902 the Referendum League secured the required number of signatures to a petition calling for a vote on the questions of municipal ownership of street railways and lighting plants and the direct nomination of candidates for city officers. At the election the total vote cast for city officers was about 200,000 , or a little more than half of the vote cast at the preceding Presidential election. The vote on the questions of public policy was about 170,000 , and was about seven to one in the affirmative on each of the three propositions. In regard to municipal ownership of street railways the actual vote was 142,826 in favor and 27,998 against. 
There has been much difference of opinion as to the significance of this vote. On its face it indicated an overwhelming popular demand. But it has been pointed out that the vote in favor of municipal ownership represented little more than a third of the total registered voters, and it has also been urged that it simply expressed the general hostility to the traction companies that had been aroused by their poor service and policy of exploitation. However the vote may be interpreted, there can be no question that it gave a renewed impetus to the demand for an act authorizing municipal ownership. To this end efforts were next directed, and in these efforts there were united both those who favored the actual establishment of a municipal system and those who desired the authority as a means of negotiating with the companies.

At the beginning of the legislative session of 1903 the prospects for any legislation opposed by the street railway companies were far from bright. Especially in the organization of the House of Representatives, the election of speaker, and the appointment of the Committee on Transportation, it was indicated that the street railway companies were working in harmony with William C. Lorimer, the boss of the Republican machine in Chicago, and with Governor Yates. Nevertheless, it was decided to make the attempt. An agreement was reached to support a measure drafted by Walter L. Fisher, secretary of the Municipal Voters' League, and introduced by Senator Müller, after whom it was named. This bill was strongly supported, not only by Mayor Harrison and the city council, but also by Graeme Stewart, Republican candidate for mayor in the election campaign of that spring, by John Maynard Harlan, who had been Mr. Stewart's active opponent for the nomination, by the Voters' League and other organizations, and by the newspaper press of Chicago, with the exception of the Inter-Ocean, which, it was known, had 
been purchased by the street railway interests. As a result of this influence, the Müller bill passed the Senate immediately after the municipal election in April; ${ }^{1}$ but it seems to have been clearly the intention to defeat the measure in the House.

The contest culminated in a dramatic situation of the highest intensity. The House Committee on Transportation, to which the Müller bill was referred, prepared a substitute measure, and a strong effort was made to induce at least some of the Chicago supporters of the Müller bill to accept this substitute. ${ }^{2}$ When this offer was refused, the House leaders decided to resort to extreme measures, as it was known that the Democrats in the House would unite with the Independent Republicans in favor of the Senate bill. The House Committee presented its substitute report, and, in the face of a demand for a roll-call from two-thirds of the members, the speaker put a series of motions, and declared them carried, whereby the substitute bill was recorded as having passed its third reading. Had this result stood, a conference committee would have been necessary; and so near was the end of the session that either the substitute bill or no legislation would have been enacted.

But the party leaders had overreached themselves. When, thru fear of personal violence, the speaker declared the House adjourned, and retired in haste to consult with the governor and his friends, ninety-seven of the one hundred and fifty-three members of the House remained in their places, and, forming a temporary organization, agreed that the appropriation bills should not be passed, and no further legislative business should be trans-

${ }^{1}$ Mayor Harrison was re-elected for a fourth term.

2 There was no opportunity for a study of this substitute bill, but it was obviously intended to defeat the effective provisions of the Müller bill, and probably contained clauses that would have greatly strengthened the position of the com-, panies. 
acted until the speaker should retrace his actions. The speaker was forced to capitulate, a reconsideration was taken, and the Müller bill was passed. The governor did not venture to refuse his signature. ${ }^{1}$

The Müller law ${ }^{2}$ is a general act authorizing any city in the State to own and operate street railways under the conditions prescribed. The act is of special significance, because, in addition to the formal grant of authority, there is a careful attempt to provide a satisfactory method for meeting the serious financial difficulties involved in the policy of municipal ownership, so that the grant of power may be effectively used by any city which considers it advisable to make use of the authority.

Before any of the powers conferred can be exercised, the act must first be adopted by popular referendum in the city concerned, while additional referendum votes must be taken in reference to various special features of the law. The authority given is "to construct, acquire, purchase, maintain, and operate street railways within the corporate limits"; and franchises granted before this power is acted on may contain a reservation of the right on the part of the city to take over the plant at some future time. Two methods are authorized for securing funds for purchasing or constructing municipal railways. General city bonds may be issued, provided the proposition is submitted to popular vote and is approved by twothirds of those voting; but debt limits are almost certain to prevent this method from being adopted. The other alternative-and this is the most striking feature of the act-is to issue street railway certificates, secured by a mortgage on the plant, giving the mortgagee in case of foreclosure the right to maintain and operate the railway for a period of not more than twenty years. Any ordi-

1 Atlantic Monthly, January, 1904.

2 Session Laws, 1903, p. 285 (May 18). 
nance providing for such certificates must, however, be submitted to popular vote and be approved by a majority of those voting on the question. It is expected that such certificates will not be considered as part of the city debt, to be included within the debt limits established by the State constitution.

When a city has secured a street railway, it may operate it under direct municipal management only if that policy is also approved at a popular referendum by three-fifths of those voting. In lieu of this the city may lease any municipal railway for a period of not over twenty years. But any ordinance authorizing a lease to a private company for more than five years must be submitted to a popular referendum on the petition of 10 per cent. of the voters.

In July, 1903, the twenty years' extension provided by the ordinance of 1883 expired. But, as no new agreement had been reached at that time and the city was not yet in a position to act under the Müller law, the various companies remained in possession, and there was no practical change in the situation. Indeed, steps had been taken in the courts which prevented the city from taking any aggressive action to oust the companies. On April 22, 1903, the Guaranty Trust Company of New York brought suit in the United States Circuit Court against the Union Traction Company and other north and west side companies; and, judgment being given and no property found, the roads were placed in the hands of receivers. These companies had been in financial difficulties for some time, as a result of the reckless issue of speculative securities. But it has been alleged that the suit was a collusive action for the purpose of having the claims of the companies under the ninety-nine years' act adjudicated in the United States courts rather than in the courts of Illinois. And, at any rate, this result was secured. On July 18 the 
receivers appointed by the court began proceedings before the United States Circuit Court to determine the rights of the companies under the acts of 1859,1861 , and 1865.

At the April election in 1904 the Müller Law was adopted by the city of Chicago by a vote of 153,000 30,000 . At the same time two questions of public policy bearing on the traction situation were submitted, with the following result:-

1. Shall the city council upon the adoption of the Müller Law proceed without delay to acquire the ownership of the street railways under the powers conferred by the Müller Law?

Yes, 121,957; no, 50,807.

2. Shall the city council instead of granting any franchises proceed at once under the city's police power and other existing laws to license the street railway companies until municipal ownership can be secured, and compel them to give satisfactory service?

Yes, 120,863 ; no, 48,200.

It should be noted that, while both.questions carried by a vote of more than two to one, the vote in favor of municipal ownership showed a falling off from the first vote in 1902, while the vote on the other side had increased.

Meanwhile the Local Transportation Committee has continued negotiations with the City Railway Company, and in August, 1904, reported a tentative ordinance in regard to the lines of that company on the south side of the city. According to this measure the claims of the company under the ninety-nine year act were to be commuted by allowing them to continue in possession for thirteen years, after which all their grants were to expire. Provisions were made for the immediate reconstruction of the lines, for extensions, and for improvements in service, 
including transfers from the lines of one company to another and some thru routes. The city was to receive 5 per cent. of the gross receipts as compensation for the use of the streets, in addition to all regular taxes on the property and franchises.

While this proposed ordinance was being discussed in the council, Judge Grosscup, of the United States Circuit Court gave his decision in the cases concerning the north and west side lines, substantially upholding the claims of the companies that all grants made before 1875 were valid until 1958. An appeal was at once taken to the United States Supreme Court. But the preliminary decision made the City Railway Company less disposed to accept the compromise in the tentative ordinance. At the same time the popular agitation in favor of municipal ownership was steadily increasing. And, as a result, the winter of 1904-05 passed with no definite advance towards a settlement of the situation.

\section{IV.}

In the municipal campaign of 1905 the street railway question was even more prominent than in previous elections, and was, in fact, the one dominant issue. The Republicans nominated for mayor John M. Harlan, formerly an opponent of the bosses of the old party machine and a leader in the council in the earlier stages of the contest with the companies. At the outset of the campaign he seemed to favor the adoption of the tentative ordinance, as a step towards effective ultimate municipal ownership at the end of the thirteen years. But before the end of the campaign he had spoken more definitely in favor of earlier action. The Democrats, abandoning the more conservative policy followed by Mayor Harrison in 
harmony with the Republican council, nominated for mayor Judge E. F. Dunne on a platform calling for immediate municipal ownership and operation. This, it was promised, could be inaugurated by using the lines where the franchises had clearly expired; and, in the case of franchises which might be held valid, either by condemnation proceedings or by building new lines parallel to those covered by unexpired franchises.

As the outcome, Judge Dunne was elected by a majority of 20,000. At the same time three more public policy votes were taken, which again indicated on their face the strong popular sentiment against any continuation of the franchise policy. These were as follows:-

1. Shall the city council pass the tentative ordinance? Yes, 64,391; no, 150,785.

2 . Shall the city council pass any ordinance granting a franchise to the City Railway Company?

Yes, 60,020; no, 151,974.

3 . Shall the city council pass any ordinance granting a franchise to any street railroad company?

Yes, 59,013; no, 152,135.

It soon became clear that there would be little active co-operation between Mayor Dunne and the city council. The council had a Republican majority; but this was not of especial significance, as a number of Republican members favored the mayor's policy. On the other hand, a number of Democratic members were not in favor of immediate municipal ownership and operation. Nevertheless, the council recognized the result of the election by reorganizing the Local Transportation Committee. Alderman Foreman was retired as chairman, and in his place Alderman Charles Werno was selected, a Democrat and a supporter of the mayor's policy. Several plans of procedure were proposed by the mayor; but action on these was defeated or postponed, either in the committee or in the 
council. ${ }^{1} \quad$ In the latter part of the year, negotiations were again renewed with the representatives of the companies; and a second tentative ordinance was prepared and reported to the council. But this ordinance did not prove satisfactory even to many of those opposed to the policy of inmmediate municipal ownership. And it was understood that leaders in the Voters' League and the independent newspapers declined to support it.

Under these circumstances the council decided to submit to the voters at the election in April, 1906, the question of authorizing an issue of $\$ 75,000,000$ of street railway certificates, under the provisions of the Müller Law, with which to purchase or construct street railways; and also the question of municipal operation. At the same time there was submitted, under the public policy act, a general question whether the city should proceed under the Müller Act in preference to passing franchise ordinances. The result of these votes was as follows:-

(1) On the issue of Mïller Law certificates $=110,225$

No.

(1) On the issue of Müller Law certificates - 110,225 106,859

(2) On municipal operation . . . . . . 121,916 110,323

(3) Public policy question . . . . . . . 111,955 108,087

${ }^{1}$ An interesting episode was that connected with the visit of Mr. Dalrymple, general manager of the municipal tramways of Glasgow, Scotland. Immediately after his election Mr. Dunne cabled to the Lord Provost of Glasgow, requesting the Glasgow authorities to allow their tramway manager to visit Chicago. It was afterwards explained that Mr. Dunne had acted on the advice of Mayor Johnson of Cleveland, and that the latter had in mind Mr. Young, the former manager of the Glasgow lines, who by the irony of fate had gone to London to take charge of Mr. Yerkes's new undertakings there. Mr. Dalrymple came to Chicago, saw Mayor Dunne and his friends, but was not brought into communication with the Council Committee on Local Transportation. He did, however, meet some of the representatives of the companies, and looked over the situation in Chicago and other American cities. When his report was received, Mayor Dunne declined to make it public on the ground that Mr. Dalrymple had been his personal guest. Eventually, the council secured a copy of this report thru the Glasgow Town Council. The first report was brief and rather vague, recommending an agreement with the companies on account of the difficulties of municipalization, among which were mentioned the ninety-nine-year act, the methods of municipal work in the United States, and the detached nature of the expiring franchises. A second report, sent at the special request of Mayor Dunne, discussed methods of administration. 
The vote on the first question definitely authorized the issue of street railway certificates under the statute. But it has been recognized that there is some doubt whether the courts will recognize the validity of the provisions in the law excluding such certificates from the city debt limit. And this legal question had to be determined before active measures could be taken. The vote on municipal operation, altho showing a larger majority in its favor, was not equal to the three-fifths vote required by the Müller Law; and that part of the mayor's policy was, for the time at least, defeated. The vote on all of the questions showed a large increase over the previous referendum votes, a notable decline in the vote in favor of municipalization, and an enormous increase of the vote in opposition.

Just before the election the legal situation was clarified by a decision of the United States Supreme Court, in effect overruling the decision of the Circuit Court as to the rights of the companies under the ninety-nine year act. The Supreme Court decided against some of the arguments presented for the city, denying the jurisdiction of the United States courts and the constitutionality of the act of 1865. But, in interpreting that act, the court held that, while it clearly extended the corporate life of the older companies for a period of ninety-nine years, the ambiguous clause on which the claims to an extension of the franchises were based must be interpreted in accordance with the established principle "that one who asserts private rights in public property under grants of the character of those under consideration must, if he would establish them, come prepared to show that they have been conferred in plain terms, for nothing passes by the grant unless it be clearly stated or necessarily implied." As Chief Justice Taney had said in an earlier case, "The rule of construction in cases of this description ... is this, that any ambiguity in the terms of the grant must operate 
against the corporation and in favor of the public, and the corporation can claim nothing that is not clearly given by the law." 1

Applying this principle, it was held that "it cannot be successfully maintained that the act of 1865 contains a clear expression of legislative intention to extend the franchise of these corporations to use the streets of Chicago, without reference to the assent of the city, for the long term of ninety-nine years; and for that time preventing other and different legislation restricting the grant of a practically exclusive right."

A dissenting opinion was filed by Justice Kenna, with whom Justices Brewer and Brown concurred, upholding the claims of the companies on the ground that the clause clearly intended to confer such a grant, and that this interpretation was confirmed by the opposition to the act and the arguments presented in Governor Oglesby's veto message.

In discussing some minor points, the court recognized the distinction in the terms of the earliest grants by the city, on which the companies' rights now rested. While on the north side the earlier grants had all definitely expired, on the south and west sides the franchises continued until the city should purchase the plant and equipment. ${ }^{2}$

As a result of this decison, the position of the city was greatly strengthened as against the companies, which had left merely a few detached pieces of street railway line, built under later franchises, and on the south and west sides the right to compensation for their cars and tracks.

1 Perine v. Chesapeake \& Canal Co., 9 Howard, 172. Cf. Chas. River Bridge v. Warren Bridge, 11 Peters, 429; Binghamton Bridge v. Binghamton Bridge Co., 3 Wallace, 51, 75; North-western Fertilizing Co. v. Hyde Park, 97 U. S. 659; Stidell v. Grandgean, 111 U. S. 412; Corson Mining Co. v. South Carolina, 144 U. S. 550; Knoxville Water Co. v. Knoxville, 200 U. S. 22, 34.

2 Blair v. Chicago, 201 U. S. 400. 
At the same time the local election had committed the city to the policy of municipal ownership, but had also blocked any immediate municipal operation. This situation caused both the mayor and the companies to modify their attitude.

On the mayor's side this change was first indicated by the retirement of Mr. Clarence S. Darrow from the position of special legal adviser on street railway matters, and the appointment to that place of Mr. Walter L. Fisher, who had been secretary and later president of the Municipal Voters' League, and had drafted the original Müller bill. This appointment was followed by a bitter and unwarrantable attack on Mr. Fisher by some of the former opponents of the mayor's policy. But it proved to be one of the wisest steps taken by the mayor, and the settlement which has been adopted is due in very large part to Mr. Fisher. On April 27, 1906, Mayor Dunne, doubtless with the advice of his new counsel, addressed a letter to Alderman Werno, chairman of the Committee on Local Transportation, outlining a plan for a prompt settlement, on the following basis:-

(1) An agreement with the companies for the purchase of their property and unexpired rights at a fixed price.

(2) The temporary continued operation of the lines by the companies under a revocable license.

(3) Immediate reconstruction of the system and improvements in the service, the cost to be repaid when the city should take possession.

(4) Profits, above a fair return to the companies upon their present and future investments, to be divided with the city.

On their part the companies accepted the general principles of this plan. Negotiations were again opened between their representatives and the Local Transportation Committee, with the mayor and his special counsel, Mr. 
Fisher, in regular attendance. It is of interest, also, to note that one of the prominent legal advisers in these later proceedings has been John M. Harlan, who was appointed by Judge Grosscup in connection with the litigation and receivership of the north and west side lines, as representative of the court.

A basis for agreement having been reached, one of the most important problems was to determine the value of the existing plant and unexpired franchises. For this purpose a special commission of engineering experts was appointed, consisting of Bion J. Arnold, who had been employed by the Local Transportation Committee for several years, Mortimer E. Cooley, dean of the Department of Engineering in the University of Michigan, who had directed an exhaustive investigation of the physical value of the railroads of Michigan a few years before, and A. B. DuPont, the mayor's engineering adviser. In September the companies submitted their estimates, which aggregated $\$ 73,555,000$. About one-third of this was for franchises, on the assumption that their remaining rights were equivalent to an average of seven years on all the existing lines. But the Commission's report, made in December, reduced these figures by more than a third. A comparative summary of the two estimates is given below:--

\begin{tabular}{|c|c|c|c|c|}
\hline & $\begin{array}{l}\text { Physical } \\
\text { Property. }\end{array}$ & Franchises. & $\begin{array}{l}\text { Total } \\
\text { without } \\
\text { Paving. }\end{array}$ & $\begin{array}{l}\text { Total } \\
\text { including } \\
\text { Paving. }\end{array}$ \\
\hline $\begin{array}{l}\text { Chicago City Railway: } \\
\text { Company's valuation } \\
\text { Commissioners' valuation : }\end{array}$ & $\begin{array}{r}\$ 20,103,936 \\
16,782,147\end{array}$ & $\begin{array}{r}\$ 10,332,228 \\
3,754,363\end{array}$ & $\$ 20,536,510$ & $\begin{array}{r}\$ 30,436,164 \\
22,369,068\end{array}$ \\
\hline $\begin{array}{l}\text { Chicago Union Traction Co.: } \\
\text { Company's valuation } \\
\text { Commissioners' valuation : }\end{array}$ & $\begin{array}{r}\$ 29,294,471 \\
20,853,629\end{array}$ & $\begin{array}{r}\$ 13,825,040 \\
5,262,608\end{array}$ & $\$ 26,116,237$ & $\begin{array}{r}\$ 43,119,511 \\
28,625,714\end{array}$ \\
\hline $\begin{array}{l}\text { Both companies: } \\
\text { Company's valuation } \\
\text { Commissioners' valuation : }\end{array}$ & $\begin{array}{r}849,398,407 \\
37,635,776\end{array}$ & $\begin{array}{r}\$ 24,157,268 \\
9,016,971\end{array}$ & $\$ 46,652,747$ & $\begin{array}{r}\$ 73,555,675 \\
50,994,782\end{array}$ \\
\hline
\end{tabular}


The commissioners' valuation for physical property was about $\$ 10,000,000$ more than the valuation determined in an investigation by the Arnold Company in 1902. This was due in part to the increased price of materials on which the estimates were based, and in part to new equipment that had been added since the earlier valuation. In other respects the valuation must be considered as fairly liberal to the companies. The physical property was valued on the basis of the cost of reconstruction at existing prices, less allowances for depreciation. The cable roads on the south and west sides were valued as operating lines (although it was evident the plant must be discarded in the reconstruction work) in recognition of the fact that the companies had a legal right to operate these lines until purchased by the city. On the other hand, the north side lines, where the city was under no legal obligation to purchase at all, were estimated at the value of the equipment in a reconstructed system. Whether the city should repay the companies for street paving was left an open question in the commissioners' report. The franchise values were determined by estimating the unexpired franchises not as detached lines, but as part of the existing systems. And to this were added the estimated profits on all the existing lines for a period of eighteen months, which period, it was estimated, would elapse before the city could take possession of the property by eminent domain or other compulsory proceedings.

In the end the representatives of the companies agreed to accept the round sum of $\$ 50,000,000$ for the physical property and existing franchise rights. This was practically the Commissioners' figures, allowing the companies the greater part of their claim for street paving. A comparison of this amount with the capitalization of the companies $(\$ 117,000,000$ in 1901$)$ shows to what extent the capital had been inflated on the basis of the claims under 
the ninety-nine year act. Indeed, three-fourths of the stock and bonds of the north and west side lines have now no substantial value.

While these valuations were being determined, negotiations proceeded on other points. Arrangements have been made for the reorganization of the companies in the hands of receivers and for the organization of a new companythe Chicago Railways Company - to take over the operation of the lines and furnish capital for the rehabilitation of the whole system. The cable roads are to be reconstructed. Subways are to be provided in the business district. Extensions and new equipment are to be furnished. For this purpose it is estimated that $\$ 40,000,000$ will be needed. It has been provided that this shall be spent under the supervision of three engineers, two of them designated by the city. The companies, however, are to be allowed 10 per cent. as contractor's profit, and 5 per cent. brokerage over the actual cost of construction, if the city should purchase the plant.

Arrangements for the operation of the lines are much more distinctly in the interest of the city and the public than in either of the previous tentative ordinances. The companies are to operate on a license revocable at any time on six months' notice, the city having the right to purchase at the stipulated price of $\$ 50,000,000$ for the existing plant plus the cost of improvements. All of the lines are to be operated as parts of one system, with a considerable number of thru routes and transfers from one district to another. The city is to have a large measure of control over the frequency of service and supervision over the accounts of the company. And the profits, after paying operating expenses, taxes, and 5 per cent. on the actual investment, are to be divided,55 per cent. to the city and 45 per cent. to the company. The plan. as a whole, may be called one establishing a 
joint partnership between the cities and companies for the control and operation of the street railways.

By the middle of January, 1907, the agreement between the council committee and the representatives of the companies had been drafted in the form of proposed ordinances and submitted to the council. Until the previous month it had seemed probable that the arrangements would prove satisfactory to all parties, and the ordinances might be passed promptly. But in the latter part of December some of the more radical advocates of municipal ownership raised objections, apparently fearing that improved service on the part of the companies would satisfy the public, and that the provisions for municipal operation would not be utilized. It is true that this may be the result. But for the friends of municipalization to urge this seems a confession of weakness in their argument that any system of regulation is bound to fail. Mayor Dunne, who had co-operated in the work of drafting the ordinances, suddenly joined this late movement, which took the form of demanding a popular referendum on the proposed ordinances. Once this demand was made, however, it should have been evident that it must be granted; and the attempt of some supporters of the agreement to oppose the movement was clearly a tactical error. Petitions calling for a referendum were signed by 189,000 names; and it was soon acknowledged that this must be provided.

In a tense and dramatic all-night session on February 4-5, 1907, the ordinances came before the council for action. Some minor amendments were accepted by the committee and adopted. A large number of others presented by the opponents were defeated. Many of these would have been to the interest of the city and the public. But the representatives of the company had declined to accept them; and, in the opinion of the majority of the 
council, they were not of sufficient importance to cause the defeat of the agreement that had been reached. Another contest arose on the precise form in which the referendum should be submitted. It is fair to note that the opponents of the ordinance are all classed among the honest, but not always among the most able, members of the council, and that the few remaining "gray wolves" voted with the majority. Chairman Werno and a majority of the Democratic members of the council declined to follow the mayor in his latest change of attitude, and supported the ordinances. In the end the council passed the ordinances by a vote of 55 to 14 , subject to the result of a referendum at the municipal election in April. Mayor Dunne declined to sign them; but they were repassed over his veto at the next session of the council.

For two months, from the passage of the ordinances by the council until the municipal election, the question as to their ratification or defeat has been the all-important issue before the people of Chicago. Around it centred the contest for city officials. The Republicans, nominating for mayor F. A. Busse, recently appointed postmaster of the city, strongly indorsed the ordinances. The Democrats, renominating Mayor Dunne, declared in favor of municipalization through condemnation proceedings. But party lines were not strictly followed; and notably a majority of the Democratic aldermen, while supporting their party candidates, were also in favor of the ordinances. Other questions, which it is not necessary to consider here, also entered to some extent into the campaign for city officers. In the outcome the ordinances were approved by a vote of 165,846 to 132,720 ; while Mr. Busse and most of the Republican ticket were elected by much smaller pluralities.

On April 18 the Supreme Court of Illinois rendered a decision in the case involving the validity of the Müller 
Law certificates, and held that these certificates must be included as part of the city debt, inasmuch as they were to be guaranteed by a right to operate street railways as well as by the physical property of the roads. This ruling, with the existing limitations on city debt, make it practically impossible for the city to purchase or build a strictly municipal railway without a change in the state constitution; and the provisions in the new agreement for municipal purchase will therefore be inoperative. It will be possible, however, under the agreement, for the city to transfer the rights to other licensee companies, on payment for the value of the property, with 20 per cent. in addition, if transferred to another profit-making company within twenty years.

V.

In attempting to draw some general conclusions from this contest, which rivals in duration and interest the Trojan War, it is necessary to emphasize some points that are likely to be overlooked, if attention is paid only to the latest stage in the conflict. In the first place, the duration of the controversy is evidence of the tenacity of purpose on the part of the people of Chicago in resisting the efforts of the financial promoters to perpetuate their control. The public policy votes on the earlier tentative ordinances showed that no franchise drawn on the traditional American lines would be acceptable.

In the second place, it will be a mistake to assume that the adoption of the present ordinances indicates that the popular demand for municipalization was merely a temporary wave of sentiment, which is now fast receding. The demand for municipalization was indeed aroused by the intolerable service and the hostile attitude of the 
companies, and, so long as the companies maintained their former position, municipalization seemed to be the only alternative policy. But it must not be overlooked that the actual vote against the ordinances was almost as large as the first vote for municipal ownership in 1902, and larger than either of the subsequent votes in favor of municipalization. The latest vote indicates that the ordinances have been approved by the action of those who were not willing to vote in former years for municipalization but were also not willing to vote for any of the alternative plans then presented.

In the third place, as stated at the outset, these ordinances set a new standard in the relations between street railway companies and public authorities in this country. They establish on a new basis the old doctrine of public ownership of the streets, and effective public control over any private company which receives special privileges in the public highways. The revocable license is a much more tangible feature than the nominal power of revocation in Massachusetts franchises, as in the Chicago ordinances there are explicit means provided by which the lines can be taken from the companies with whom the present agreement is made. And the division of profits, supplementing the system of public control, makes the city in fact an active partner in the street railway business.

As to the future, the firm believers in and the convinced opponents of municipalization will each have their own predictions. The writer believes that there is a fair promise that, if the companies carry out their part of the agreement and co-operate heartily with the city authorities, there will be no further steps in the direction of municipalization for many years. But if the service is not brought promptly to a satisfactory standard, or if there should be a revival of the policy of speculative finance or political manipulation, the city will not remain 
entirely at the mercy of the present companies. In that case there may be a trial of the so-called "contract plan," by which the street railways would be transferred to a licensee corporation acting as trustee for the city. Or it is not impossible that the State Constitution may be amended to provide an effective means for municipalization.

\section{UnIVERSITY OF Michigan.}

JohN A. FAIRLIE.

\section{BIBLIOGRAPHICAL NOTE.}

There is a voluminous mass of printed material on the Chicago Street Railways, but it is widely scattered, and there is nothing approaching a complete collection in one place. Among primary sources may be mentioned the official records of the Illinois State legislature and the City Council of Chicago, and the judicial reports on the litigated questions. The most important documents have also been reprinted, and in addition there have been scores of pamphlets and articles in periodicals. A list of documents, pamphlets, and longer articles, excluding items in the daily and weekly press, would contain more than a hundred titles, and only the more important among them are given in the following list.

\section{Official Documents:}

Mayor Carter H. Harrison: Special Message January 6, 1902, and Annual Messages, May 25, 1903, April 11, 1904, and April 10, 1905.

Mayor Edward F. Dunne: Annual Messages, April 11, 1906, and April 15, 1907. Letter to Alderman Charles Werno, April 27, 1906.

Council Committees:

Report of the Special Committee of the City Council of Chicago on Street Railway Franchises, March, 1898.

Report of the Street Railway Commission, December, 1900.

Report of the Special Committee on Local Transportation, outlining the provisions of a renewal ordinance, December, 1901.

An ordinance granting rights to the Chicago City Railway Company (tentative ordinance), July 23, 1904.

Report of the Committee on Local Transportation, and ordinances, January 15, 1907.

Bion J. Arnold: Reports on Engineering and Operating Features of the Chicago Transportation Problem, 1902-1906.

Traction Valuation Commission: Report on the Values of the Tangible and Intangible Properties of the Chicago Street Railway Companies, December $10,1906$.

Judicial Reports:

Circuit Court of the United States: Guaranty Trust Co. v. Chicago Union Traction Co., etc. 1903 (over 20 vols.).

Supreme Court of the United States: H. A. Blair et al. v. City of Chicago, and other cases, 201 U. S. 400 (1906).

Supreme Court of Illinois: Lobdell et al. v. City of:Chicaoo (1907). 


\section{Special Pamphlets:}

History and Statistics of Chicago Street Railway Corporations (Supplement to the Economist), 52 pp. Maps. Chicago, 1896.

List of Franchises, 1837-1896. Chicago, J. F. Higgins, 1896.

Illinois Bureau of Labor Statistics: The Street Railways of Chicago and Other Cities (1897).

\section{Articles in Periodicals:}

Quarterly Journal of Economics, vol. xii. 83 (J. H. Gray).

Municipal Affairs, vol. v. 439-594 (Report of Civic Federation).

National Conference for Good City Government, 1902 (George C. Sikes).

Atlantic Monthly, vol. xciii. 109 (E. B. Smith).

American Law Review, vol. xxxix. 244.

Annals of the American Academy of Social and Political Science, vol. xx. 356; vol. xxvii. 72 ; vol. $x x i x .385$.

International Quarterly, vol. xii. 13 (C. S. Darrow).

Review of Reviews, vol. xxxiii. 549.

Three collections of material of special value should be noted: (1) that of Professor John H. Gray, of Northwestern University (the best single collection), which includes the voluminous record of the Circuit Court proceedings, two large bound volumes of documents and miscellaneous pamphlets, and a manuscript thesis by George B. Goodwin on "The History of the Chicago Street Railways"; (2) that of the John Crerar Library, which includes a bound volume of documents, pamphlets, and newspaper clippings connected with the Humphrey-Allen Bills of 1897, by George E. Hooker, a box of pamphlets, and also other documents separately catalogued; and (3) that of the City Club of Chicago, which includes two boxes of miscellaneous documents and pamphlets. While there is some duplication each of these contains important material not in the others. There are, in addition, a good number of pamphlets and special reports not in any of these collections.

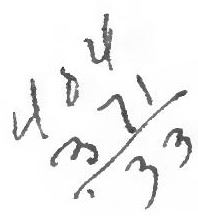




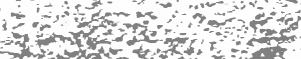

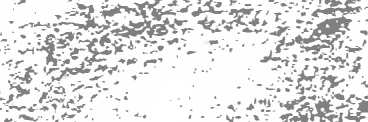

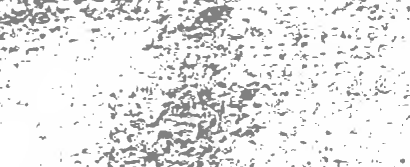

ats

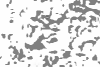

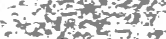

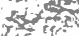

in

in

and

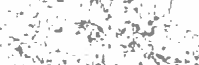

ond it 


\section{UNIVERSITY OF CALIFORNIA LIBRARY BERKELEY}

\section{THIS BOOK IS DUE ON THE LAST DATE}

\section{STAMPED BELOW}

Books not returned on time are subject to a fine of $50 \mathrm{c}$ per volume after the third day overdue, increasing to $\$ 1.00$ per volume after the sixth day. Books not in demand may be renewed if application is made before expiration of loan period.

\section{APR 141919 \\ 13 MY $59 E S$ \\ PRECDLLO \\ PliRY 191959 \\ Jun2'59WP i \\ RECD LD

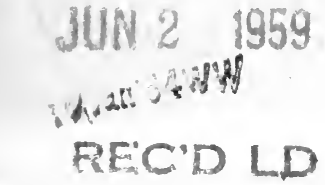 \\ JAN 8'64-8.PM}




\section{8}

$$
\begin{aligned}
& \text { HE } 4+-11 \\
& \text { C. } 47 F_{2}
\end{aligned}
$$

UNIVERSITY OF CALIFORNIA LIRRARY 
